Original Article

\title{
Enterotoxigenic methicillin resistant Staphylococcus aureus contamination in salted fish from Gwadar Balochistan
}

\author{
Contaminação de Staphylococcus aureus resistente à meticilina enterotoxigênica em \\ peixes salgados de Gwadar Balochistan
}

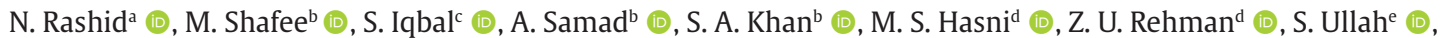 \\ F. U. Rehman a (D, G. I. Khan ${ }^{\mathrm{a}}$ (D), S. Ahmad ${ }^{\mathrm{a}}$ (D) and A. Akbar ${ }^{* *}$ (D) \\ aUniversity of Balochistan, Department of Microbiology, Quetta, Pakistan \\ bUniversity of Balochistan, Center of Advanced Studies in Vaccinology and Biotechnology - CASVAB, Quetta, Pakistan \\ 'University of Information Technology Engineering and Management Sciences, Department of Chemistry Balochistan, Quetta, Pakistan \\ dUniversity of Balochistan, Institute of Biochemistry, Quetta, Pakistan \\ eUniversity of Balochistan, Department of Chemistry, Quetta, Pakistan
}

\begin{abstract}
Staphylococcus aureus is an important foodborne pathogen associated to food intoxication and other multiple infections in human being. Its presence in salted food is a serious issue due to its salt tolerance potential. A study was conducted to analyze the presence of enterotoxins producing drug resistance $S$. aureus in salted sea fish from Gwadar. Freshly persevered samples ( $\mathrm{n}=50$ ) of salted fish were subjected to analyze the presence of $S$. aureus using $16 \mathrm{~S}$ rRNA and Nuc genes primers. The isolates were then evaluated for drug resistance and enterotoxins producing potential using specific primers for MecA (methicillin resistance gene), (SEA) staphylococcal enterotoxin A and (SEB) staphylococcal enterotoxin B genes. Total 13/50 (26\%) of the samples were found positive for the presence of $S$. aureus, preliminary confirmed with biochemical profiling and finally with the help of target genes presence. The isolates were found showing $100 \%$ resistant to methicillin, which were molecularly confirmed by the presence of MecA gene present in genome. The isolates 5/13 (38\%) were positive for SEA and 3/13 (23\%) for SEB genes, whereas 2/13 (15\%) were confirmed having both SEA and SEB genes in its genome. It was also confirmed that all the isolates were capable to form biofilm over the glass surfaces. It was concluded that the study confirmed the presence of enterotoxigenic methicillin resistance Staphylococcus aurous (MRSA) in salted fish product, that poses gross food safety concern. Preventive and control measures are necessary to handle this serious food safety concern.
\end{abstract} Keywords: antimicrobials, food safety, public health, pathogens, foodborne diseases.

\begin{abstract}
Resumo
Staphylococcus aureus é um importante patógeno de origem alimentar associado à intoxicação alimentar e outras infecções múltiplas em seres humanos. Sua presença em alimentos salgados é um problema sério devido ao seu potencial de tolerância ao sal. Um estudo foi realizado para analisar a presença de enterotoxinas produtoras de resistência a drogas $S$. aureus em peixes salgados do mar de Gwadar. Amostras recém-perseveradas $(n=50)$ de peixes salgados foram submetidas à análise da presença de $S$. aureus usando os primers dos genes $16 \mathrm{~S}$ rRNA e Nuc. Os isolados foram então avaliados quanto à resistência a drogas e potencial de produção de enterotoxinas usando primers específicos para os genes MecA (gene de resistência à meticilina), (SEA) enterotoxina A estafilocócica e (SEB) enterotoxina B estafilocócica genes. Um total de 13/50 (26\%) das amostras foi considerado positivas para a presença de $S$. aureus, confirmadas preliminarmente com perfis bioquímicos e finalmente com a ajuda da presença de genes-alvo. Os isolados foram encontrados com 100\% de resistência à meticilina, os quais foram confirmados molecularmente pela presença do gene MecA no genoma. Os isolados 5/13 (38\%) foram positivos para SEA e 3/13 (23\%) para genes SEB, enquanto 2/13 (15\%) foram confirmados tendo os genes SEA e SEB em seu genoma. Também foi verificado que todos os isolados foram capazes de formar biofilme sobre as superfícies de vidro. Concluiu-se que o estudo confirmou a presença de Staphylococcus aurous resistente à meticilina enterotoxigênica (MRSA) em produtos de peixe salgado, o que representa uma grande preocupação para a segurança alimentar. Medidas preventivas e de controle são necessárias para lidar com essa grave preocupação com a segurança alimentar.
\end{abstract}

Palavras-chave: antimicrobianos, segurança alimentar, saúde pública, patógenos, doenças transmitidas por alimentos.

*e-mail: aliakbar.uob@gmail.com

Received: January 18, 2021 - Accepted: March 9, 2021

This is an Open Access article distributed under the terms of the Creative Commons Attribution License, which permits unrestricted use, distribution, and reproduction in any medium, provided the original work is properly cited. 


\section{Introduction}

Seafood including fish meat are the chief source of animal protein in the diet. Consumption of seafood specifically fish are increasing due to its health advantages over red meat and other food products (Laskowski et al., 2018). It is considered as valuable food due to the presence of protein and unsaturated fat content. The fatty acids such as, Omega-3 and other polyunsaturated fatty acid are known for its anti-inflammatory and anti-cardiovascular capabilities (Mei et al., 2019). Meat and fish are highly perishable and vulnerable to microbial contaminated during its processing and storage (Frozi et al., 2017).

Several foodborne pathogens have been reportedly associated with fish contamination (Akbar and Anal, 2011). Staphylococcus aureus is amongst one of the leading cause of food contamination, which can spoil the food by producing lethal enterotoxin (Akbar et al., 2014). This Gram-positive bacterium is potentially causing foodborne intoxications, and other associated infections. The enterotoxins SEA and SEB produced by the bacterium are heat stable and resist most proteolytic enzymes (Rall et al., 2010). Enterotoxins coding genes are present on the genomic DNA. The release of these enterotoxins in food commodities are responsible for food poisoning (Nawrotek et al., 2005).

Contamination of seafood with drug resistance and virulent species of $S$. aureus can create serious food safety and public health issues. Enterotoxin producing MRSA can be more fatal and problematic compared to its drug sensitive counterpart (Mirani et al., 2017). MRSA are potent to show higher drug resistance, that makes them more virulent, the MecA gene present in Mec operon of staphylococcal chromosome are responsible for the expression of methicillin resistance (Vaiyapuri et al., 2019).

S. aureus is part of normal microbial flora and is living in different body parts of human and animals. Its resistant strains are emerging due to the excessive uses of antibiotics in human and animals farming (Grema et al., 2015). The biofilm formation ability of these microbes can make it more dangerous in food processing industries (Zahoor and Bhatia, 2007). The entry of S. aureus to food product can take place during processing and transportation. Its entry in fish product cannot be ruled out from the water and fish habitat (Samad et al., 2019). It is important to study the presence of pathogens in fish and seafood products in order to ensure its safety and for better understanding of microbial ecology and its control (Novoslavskij et al., 2016). This is a first of its kind of study in the area, focused to detect the presence of $S$. aureus in salted fish of Gwadar Balochistan and to analysis its virulence and drug resistance potential.

\section{Material and Method}

\subsection{Sampling}

Freshly preserved salted fish $(n=50)$ were collected form Gwadar Balochistan area and were processed for target pathogens isolation in Food Microbiology and Bioprocess Technology Laboratory Department of Microbiology and Center of Advanced Studies in Vaccinology and Biotechnology (CASVAB) University of Balochistan Quetta, Pakistan. The samples were collected in sterile bags aseptically and transported to the laboratory using samples transportation box maintain the temperature at $2 \pm 2{ }^{\circ} \mathrm{C}$ using ice pads.

\subsection{Isolation of $S$. aureus}

An amount $10 \mathrm{~g}$ of the salted fish were mixed with $90 \mathrm{~mL}$ sterile peptone water to prepare 1:10 dilution for enrichment of the target bacterial species, and incubated at $37^{\circ} \mathrm{C}$ for 6 hours (Akbar and Anal, 2015). Amount $0.5 \mathrm{~mL}$ from three different dilutions was inoculated over Mannitol Salt Agar (MSA) in triplicate and incubated at $37^{\circ} \mathrm{C}$ for 24 hours. Appearance of yellow colonies were refreshed in MSA plates preliminary confirmed as $S$. aureus with the help of Grams staining, coagulase, urease and catalase production. The pure subculture was preserved for further analysis (Akbar and Anal, 2014).

\subsection{DNA extraction and molecular conformation}

For molecular confirmation the DNA of preliminary confirmed isolates were extracted by boiling method following Oliveira et al., (2014) with slight modification. Precisely the $1 \mathrm{~mL}$ fresh culture were taken and centrifuged for 10 minutes at $14000 \mathrm{rpm}$. The supernatant was discarded, and pellet was suspended in $400 \mu \mathrm{L}$ of (1x) TE buffer (Tris Ethylene Diamine Tetra Acetic acid (EDTA). It was kept in water bath at $94{ }^{\circ} \mathrm{C}$ for 15 minutes and subsequently centrifuged at $6000 \mathrm{rpm}$ for 10 minutes. The supernatant containing DNA was stored at $-20{ }^{\circ} \mathrm{C}$ till further use.

For molecular confirmation of $S$. aureus, the $16 \mathrm{~S}$ rRNA (228bp amplicon size) F' CGCACATCAGCGTCAG, R' GTAGGTGGCAAGCGTTATC and Nuc gene primer (279bp amplicon size) F' GCGATTGATGGTGATACGGTT, R' AGCCAAGCCTTGACGAACTAA AGC were used. PCR reaction $(20 \mu \mathrm{L})$ for $16 \mathrm{~S}$ rRNA were prepared by mixing Master Mix $(10 \mu \mathrm{L})$, Forward primers $(1 \mu \mathrm{L})$, Reverse primers $(1 \mu \mathrm{L})$, DNA samples $(2 \mu \mathrm{L})$ and PCR grade water $(6 \mu \mathrm{L})$. Similarly, for Nuc gene $(25 \mu \mathrm{L})$ mixture (master mix $10 \mu \mathrm{L}$, Forward primers $1 \mu \mathrm{L}$, Reverse primers $1 \mu \mathrm{L}$, DNA samples $3 \mu \mathrm{L}$ and PCR grade water $10 \mu \mathrm{L}$ ). The PCR mixture were processed by denaturation for 5 minutes at $94^{\circ} \mathrm{C}$, denaturation for $45 \mathrm{sec}$ at $94^{\circ} \mathrm{C}$. Annealing for $45 \mathrm{sec}$ at $58^{\circ} \mathrm{C}$, extension for 1 minute and final extension for 10 minutes at $72{ }^{\circ} \mathrm{C}$ with 37 cycle for $16 \mathrm{~S}$ rRNA, and 35 cycles for Nuc gene. Agarose gel $(2 \%)$ were used for the confirmation of banding pattern comparing it with the standard DNA markers.

\subsection{Antibiogram determination}

Antibiotic sensitivity pattern of the $S$. aureus isolates was determined using Kirby-Bauer disc diffusion susceptibility protocol following Samad et al. (2019). The standard antibiotic disc used were Vancomycin $(30 \mu \mathrm{g})$, Gentamicin $(10 \mu \mathrm{g})$, Methicillin $(30 \mu \mathrm{g})$, Enrofloxacin $(5 \mu \mathrm{g})$, Spectinomycin $(25 \mu \mathrm{g})$ (Oxoid Ltd., UK.) 


\subsection{Molecular detection of methicillin resistance gene}

The MecA gene responsible for methicillin resistance in $S$. aureus were confirmed in the isolate using F' AAAATCGATGGTAAAGGTTGGC, R' AGTTCTGCAGTACCGGATTTG with amplicon size 533bp primers. PCR mix $(20 \mu \mathrm{L})$ was prepared by mixing master $\operatorname{mix}(10 \mu \mathrm{L})$, forward primers $(1 \mu \mathrm{L})$, reverse primer $(1 \mu \mathrm{L})$, PCR grade water $(3 \mu \mathrm{L})$ and DNA sample $(5 \mu \mathrm{L})$. The PCR mix were processed, initial denaturation 5 minutes at $94^{\circ} \mathrm{C}$, denaturation for $35 \mathrm{sec}$ at $94^{\circ} \mathrm{C}$, Annealing for $30 \mathrm{sec}$ at $55{ }^{\circ} \mathrm{C}$, Extension for 1 minute and final extension for 5 minutes at $72{ }^{\circ} \mathrm{C}$ with 37 cycle.

\subsection{Molecular detection of enterotoxins producing gene}

Confirmation of the enterotoxin producing genes were conducted using the staphylococcal food poisoning (SFP) staphylococcal enterotoxins A (SEA) and B (SEB) genes Arslan and Ozdemir (2017). Primers for gene SEA with F' TGTATGTATGGAGGTGTAAAC, R' ATTAACCGAAGGTTCTGT amplicon size 270bp and SEB with F' TGTATGTATGGAGGTGTAAAC, R' ATAGTGACGAGTTAGGTA amplicon size 165bp were used in the study.

The PCR mix $(25 \mu \mathrm{L})$ (master mix $10 \mu \mathrm{L}$, Forward primers $3 \mu \mathrm{L}$, Reverse primers $31 \mu \mathrm{L}$, DNA samples $5 \mu \mathrm{L}$ and PCR grade water $4 \mu \mathrm{L}$ ) were processed (initial denaturation 5 minutes $95^{\circ} \mathrm{C}$, denaturation $30 \mathrm{sec} 95^{\circ} \mathrm{C}$, annealing $45 \mathrm{sec}$ $52^{\circ} \mathrm{C}$, extension $45 \mathrm{sec}$ and final extension 1 minute $72^{\circ} \mathrm{C}$ ) for SEA and SEB with 30 cycle. The banding product were confirmed by running the products on $2 \%$ agarose gel.

\subsection{Biofilm forming capabilities determination}

Tube and slid dip method were used for the biofilm forming capabilities determination of the S. aureus isolates, by inoculating fresh $(24 \mathrm{~h})$ culture of bacteria to trypticase soya broth. The test tubes were incubated for $24 \mathrm{~h}$ at $37^{\circ} \mathrm{C}$. The test tubes were decanted, dried and stained with crystal violet. The test tubes were washed, airdried and visually observed for staining. Slide dip method was also used for biofilm formation, which were observed visually and microscopically with $100 \mathrm{X}$ (Notcovich et al., 2018). All the experiments were conducted in triplicate and analyzed using SPSS.

\section{Results}

In this study, a total of 50 samples were collected from Gwadar, that were subjected to analysis for the presence of S. aureus. It was found that $13 / 50$ (26\%) of the collected samples were positive for the target bacterial specie preliminary confirmed with the help of biochemical profiling and finally with 16S rRNA (Supplementary Material - Figure S1) and Nuc (Figure 1) gene present in its genome.

The molecularly confirmed $S$. aureus subjected to antibiograms studies revealed $100 \%$ resistance of isolates $(13 / 13)$ to methicillin and spectinomycin, whereas 5/13 (38\%), 4/13 (31\%) and 3/13 (23\%) showed resistance to gentamicin, enrofloxacin and vancomycin respectively. Methicillin resistance gene (MecA) were confined in the isolates with the help of PCR (Figure 2). It shows that all the isolates in this study were MRSA. One isolate showed resistance to five antibiotics and one to four antibiotics used in the study whereas eight and three isolates showed resistance to three and two antibiotics respectively.

Pathogenicity of $S$. aureus isolates was molecularly determined by using two different genes primer representing SEA and SEB. The enterotoxins A is more frequently associated to this organism responsible for food poisoning. It was found in this study that 5/13 (38\%) isolates are positive for SEA gene (Supplementary Material - Figure S2) and 3/13 (23\%) for SEB (Figure 3). It was also confirmed, that $2 / 13(15 \%)$ of the isolates are having both SEA and SEB genes in its genome.

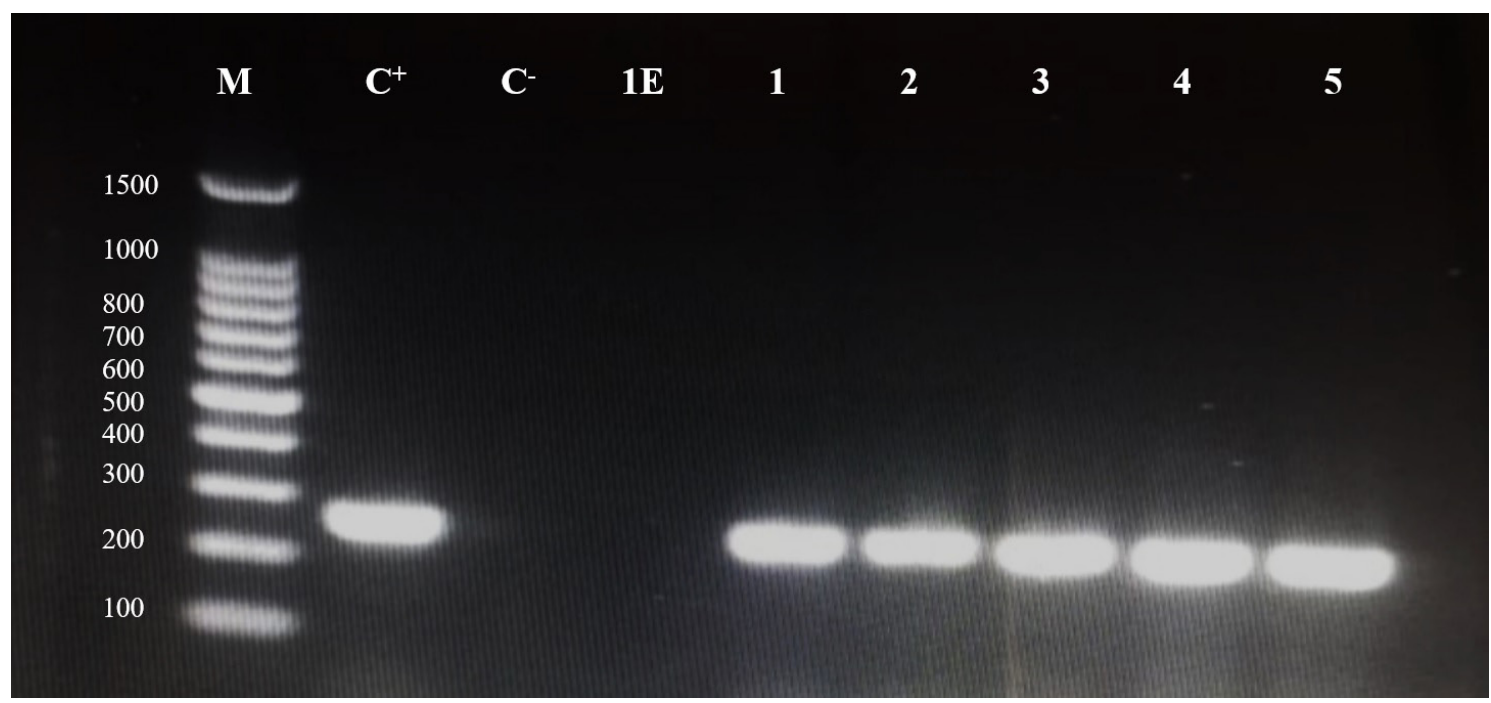

Figure 1. Represent electrophoresis of amplified gene. Lane $M=$ marker with $1000 \mathrm{bp}$. Lane $\mathrm{C}^{+}=$Positive control. Lane $\mathrm{C}^{-}=$Negative control. Lane 1E is empty. Lane 1,2,3,4 and 5 = Positive samples for Nuc gene (279bp). 

M
$\mathbf{C}^{+}$
$\mathbf{C}^{-}$
1
2
3E
4E

1500

1000

700

600

500

400

300

200

100

Figure 2. Shows electrophoresis of amplified genes. Lane $\mathrm{M}$ is maker (1000bp), Lane $\mathrm{C}^{+}=$Positive control $\mathrm{C}^{-}=$Negative control, Lane 3E, 4E = Empty, Lane 1, 2 and 5 = Positive sample for MecA gene (533bp).

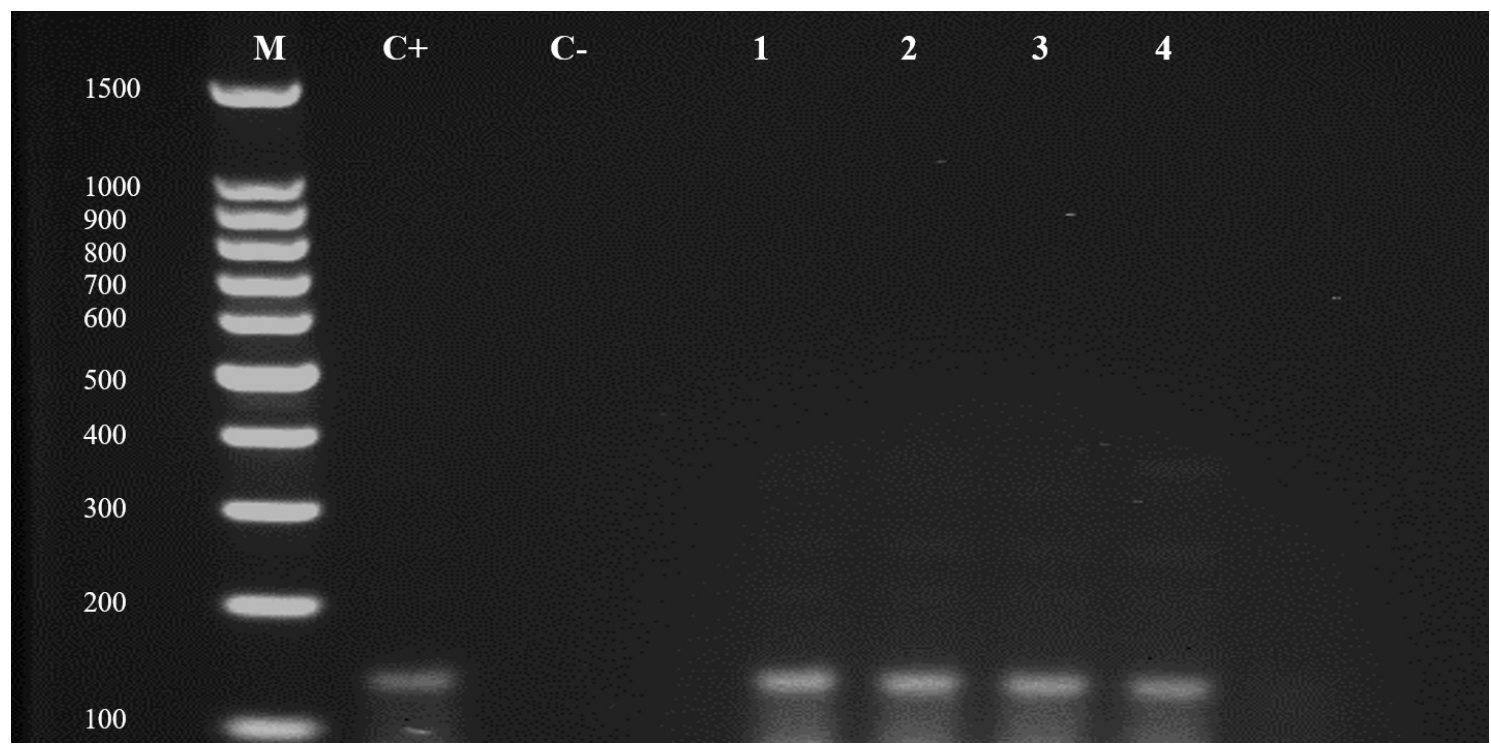

Figure 3. Gel electrophoresis of the PCR product showing amplified product of SEB gene (165bp), Lane M = Marker of $1000 \mathrm{bp}$, Lane $\mathrm{C}^{+}=$ Positive control $C^{-}=$Negative control, Lanes 1, 2, 3 and 4 = Positive samples.

It was found that all the isolates were capable to form biofilm over the surface of the glass slides, confirmed visually and microscopically.

\section{Discussion}

Staphylococcus aureus is an important foodborne pathogen, most frequently associated to enterotoxins associated intoxication (Akbar et al., 2019). Since this bacterium can grow easily in the presence of 5-15\% salt concertation, which can be a threat for salted food (Samanta and Bandyopadhyay, 2020). The safety of traditionally preserved food is compromised in the presence of $S$. aureus. Since $S$. aureus is not the normal flora of fish species and its presence in seafood and fish cannot be ignored (Tavakoli et al., 2012). In this study we found $26 \%$ prevalence of S. aureus, which are in line with the results (26\%) of the similar study reported by Arslan and Ozdemir (2017). Almost similar results of $24.5 \%$ have been reported by Bujjamma and Padmavathi (2015). Mohammed et al. (2020) reported $31 \%$ S. aureus contamination in fish from Nigeria. 
All the $S$. aureus isolates in this study showed resistance to methicillin and spectinomycin, which is alarming as the presence of MRSA in salted fish are not only the cause of food intoxication but can also lead to nosocomial infection in human beings (Saklani et al., 2020). Food has been previously reported for the cause of MRSA related blood and wound infections (Kadariya et al., 2014). Mirani et al. (2017) reported $28 \%$ S. aureus contamination from fish collected from fish markets of Karachi Pakistan, where the that $16 \%$ of the isolates were MRSA. The prevalence of drug resistance pathogens in the traditionally preserved foods is an important concern. Like our study the Yahya et al. (2020) and Egege et al. (2020) detected MecA gene in S. aureus isolates from fish conforming the methicillin resistance in the isolates. Fri et al. (2020) and Mohammed et al. (2020) found MRSA in marine fish and meat product.

Enterotoxins genes SEA and SEB associated to in S. aureus are the main causing factor of foodborne intoxication related to this specie, these toxins are clinically important, which can resist heat and digestive enzymes (Kadariya et al., 2014). Our study revealed 38\% SEA and 23\% SEB gene presence in the isolates, which shows higher frequency of SEA compared to SEB. In a similar study, Mohammed et al. (2014) reported high level of SEA (38\%) compared to SEB (35.7\%) genes from salted fish in Khartoum states Sudan. In another study, Arfatahery et al. (2016) found 45.2\% SEA and $18.5 \%$ SEB gene in S. aureus isolates from fishery products in Iran. Enterotoxins genes containing $S$. aureus contamination in salted fish products are of high food safety concern for the consumers.

It was found in the highly pathogenic MRSA isolates in this study can easily form biofilm over the surfaces. This ability of the isolates makes them more able for cross contamination of the utensils and processing surfaces, that can enhance the spread of this pathogen and outbreaks. The biofilm can reduce the effect of antimicrobial procedures over the pathogens (Akbar and Anal, 2011). The findings of our studies are in agreement with other studies, Hamad et al. (2019) reported the formation of biofilm by foodborne $S$. aureus isolated from fish, meat and other food products. The biofilm forming potential of the pathogenic bacteria is one of its important virulence factors that enhance its pathogenicity and chances of infections (Freitas et al., 2018). Whereas the quorum sensing reaction can make the pathogen more resistant to the antimicrobial drugs.

\section{Conclusion}

A significant number of $S$. aureus were collected from salted fish, which showed resistance to different antibiotics including methicillin and were detected carrying enterotoxins genes SEA and SEB. The isolates had the potential to form biofilm over the surface of glass which are an enhancing factor for pathogenicity. It was concluded that salted fish which are commonly known as preserved are not completely safe for the consumption, particularly in raw form. Attention of the processing industries are needed in this regard for the safety of consumers and growth of processing industries.

\section{References}

AKBAR, A. and ANAL, A.K., 2011. Food safety concerns and food-borne pathogens, Salmonella, Escherichia coli and Campylobacter. FUUAST Journal of Biology, vol. 1, no. 1, pp. 5-17.

AKBAR, A. and ANAL, A.K., 2014. Occurrence of Staphylococcus aureus and evaluation of anti-staphylococcal activity of Lactococcus lactis subsp. lactis in ready-to-eat poultry meat. Annals of Microbiology, vol. 64, no. 1, pp. 131-138. http://dx.doi. org/10.1007/s13213-013-0641-X.

AKBAR, A. and ANAL, A.K., 2015. Isolation of Salmonella from ready-to-eat poultry meat and evaluation of its survival at low temperature, microwaving and simulated gastric fluids. Journal of Food Science and Technology, vol. 52, no. 5, pp. 3051-3057. http://dx.doi.org/10.1007/s13197-014-1354-2. PMid:25892808.

AKBAR, A., SADIQ, M.B., ALI, I., MUHAMMAD, N., REHMAN, Z., KHAN, M.N., MUHAMMAD, J., KHAN, S.A., REHMAN, F.U. and ANAL, A.K., 2019. Synthesis and antimicrobial activity of zinc oxide nanoparticles against foodborne pathogens Salmonella typhimurium and Staphylococcus aureus. Biocatalysis and Agricultural Biotechnology, vol. 17, pp. 36-42. http://dx.doi. org/10.1016/j.bcab.2018.11.005.

AKBAR, A., SITARA, U., ALI, I., KHAN, M.I., PHADUNGCHOB, T. and ANAL, A.K., 2014. Presence of Escherichia coli in poultry meat: a potential food safety threat. International Food Research Journal, vol. 21, no. 3, pp. 941-945.

ARFATAHERY, N., DAVOODABADI, A. and ABEDIMOHTASAB, T., 2016. Characterization of toxin genes and antimicrobial susceptibility of Staphylococcus aureus isolates in fishery products in Iran. Scientific Reports, vol. 6, no. 1, pp. 34216. http://dx.doi. org/10.1038/srep34216. PMid:27694813.

ARSLAN, S. and OZDEMIR, F., 2017. Molecular characterization and detection of enterotoxins, methicillin resistance genes and antimicrobial resistance of Staphylococcus aureus from fish and ground beef. Polish Journal of Veterinary Sciences, vol. 20, no. 1, pp. 85-94. http://dx.doi.org/10.1515/pjvs-2017-0012. PMid:28525337.

BUJJAMMA, P. and PADMAVATHI, P., 2015. Prevalence of Staphylococcus aureus in fish samples of local domestic fish market. International Journal of Microbiology and Applied Sciences, vol. 4, no. 5, pp. 427-433.

EGEGE, S.R., AKANI, N.P. and NWANKWO, C.E.I., 2020. Detection of Methicillin-Resistant Staphylococcus aureus in Ready-to-Eat Shellfish (Corbiculid heterodont) in Bayelsa State, Nigeria. Microbiology Research Journal International, vol. 30, no. 3, pp. 22-35. https://doi.org/10.9734/mrji/2020/v30i330202.

FREITAS, C.H., MENDES, J.F., VILLARREAL, P.V., SANTOS, P.R., GONÇALVES, C.L., GONZALES, H.L. and NASCENTE, P.S., 2018. Identification and antimicrobial suceptibility profile of bacteria causing bovine mastitis from dairy farms in Pelotas, Rio Grande do Sul. Brazilian Journal of Biology = Revista Brasileira de Biologia, vol. 78, no. 4, pp. 661-666. http://dx.doi.org/10.1590/15196984.170727. PMid:29319754.

FRI, J., NJOM, H.A., ATEBA, C.N. and NDIP, R.N., 2020. Antibiotic resistance and virulence gene characteristics of MethicillinResistant Staphylococcus aureus (MRSA) isolated from healthy edible marine fish. International Journal of Microbiology, vol. 2020, pp. 9803903. http://dx.doi.org/10.1155/2020/9803903. PMid:32565817.

FROZI, J.B., ESPER, L.M.R. and FRANCO, R.M., 2017. Single-and multispecies biofilms by Escherichia coli, Staphylococcus aureus, and Salmonella spp. isolated from raw fish and a fish processing unit. Ciência Rural, vol. 47, no. 10. http://dx.doi. org/10.1590/0103-8478cr20170011. 
GREMA, H.A., GEIDAM, Y.A., GADZAMA, G.B., AMEH, J.A. and SULEIMAN, A., 2015. Methicillin resistant Staphyloccus aureus (MRSA): a review. Advances in Animal and Veterinary Sciences, vol. 3, no. 2, pp. 79-98. http://dx.doi.org/10.14737/journal. aavs/2015/3.2.79.98.

HAMAD, A.A., SAAD, S.M. and IBRAHIM, H.M., 2019. Biofilm formation by Staphylococcus aureus isolated from Some Egyptian Meat processing Plants and Hotels' Environments: with Special Reference to its Sensitivity to Sanitizers. Benha Veterinary Medical Journal, vol. 37, no. 1, pp. 81-85. http://dx.doi. org/10.21608/bvmj.2019.16273.1082.

KADARIYA, J., SMITH, T.C. and THAPALIYA, D., 2014. Staphylococcus aureus and staphylococcal food-borne disease: an ongoing challenge in public health. BioMed Research International, vol. 2014, pp. 827965. http://dx.doi.org/10.1155/2014/827965. PMid:24804250.

LASKOWSKI, W., GÓRSKA-WARSEWICZ, H. and KULYKOVETS, O., 2018. Meat, meat products and seafood as sources of energy and nutrients in the average Polish diet. Nutrients, vol. 10, no. 10, pp. 1412. http://dx.doi.org/10.3390/nu10101412. PMid:30279395.

MEI, J., MA, X. and XIE, J., 2019. Review on natural preservatives for extending fish shelf life. Foods, vol. 8, no. 10, pp. 490. http:// dx.doi.org/10.3390/foods8100490. PMid:31614926.

MIRANI, Z.A., AQEEL, A. and NAZ, S., 2017. Prevalence of staphylococci in commercially processed food products in Karachi-Pakistan. Journal of Microbiology and Infectious Diseases, vol. 7, no. 2, pp. 83-87. http://dx.doi.org/10.5799/ jmid.328789.

MOHAMMED, T.A., KHALID, A.E. and SAADABI, A.M., 2014. PCR Deyection of Staphylococcal Enterotoxin A and B Genes in Staphylococcus aureus Isolated from Salted Fermented Fish. Microbiology Journal, vol. 4, no. 2, pp. 51-56. http://dx.doi. org/10.3923/mj.2014.51.56.

MOHAMMED, U.H., BALA, A.M. and BAKO, M., 2020. Phenotypic and molecular detection of methicillin resistant Staphylococcus aureus (MRSA) Isolated from Clarias gariepinus (Burchfiel, 1822) and Oreochromis niloticus (Linneaus, 1758) IN Maiduguri. International Journal of Fisheries and Aquatic Studies, vol. 8 , no. 4, pp. 365-372.

NAWROTEK, P., BORKOWSKI, J., BOROŃ-KACZMARSKA, A. and FUROWICZ, A.J., 2005. The characteristics of staphylococcal enterotoxins produced by strains isolated from mastitic cows, including epidemiological aspects. Przegląd Epidemiologiczny, vol. 59, no. 4, pp. 891-902. PMid:16729431.

NOTCOVICH, S., DENICOLO, G., FLINT, S.H., WILLIAMSON, N.B., GEDYE, K., GRINBERG, A. and LOPEZ-VILLALOBOS, N., 2018. Biofilm-forming potential of Staphylococcus aureus isolated from bovine mastitis in New Zealand. Veterinary Sciences, vol. 5, no. 1, pp. 8. http://dx.doi.org/10.3390/vetsci5010008. PMid:29351199.
NOVOSLAVSKIJ, A., TERENTJEVA, M., EIZENBERGA, I., VALCIN̦A, O., BARTKEVIČS, V. and BĒRZIN̦Š, A., 2016. Major foodborne pathogens in fish and fish products: a review. Annals of Microbiology, vol. 66, no. 1, pp. 1-15. http://dx.doi.org/10.1007/ s13213-015-1102-5.

OLIVEIRA, C.F.D., PAIM, T.G.D.S., REITER, K.C., RIEGER, A. and DAZEVEDO, P.A., 2014. Evaluation of four different DNA extraction methods in coagulase-negative Staphylococci clinical isolates. Revista do Instituto de Medicina Tropical de São Paulo, vol. 56, no. 1, pp. 29-33. http://dx.doi.org/10.1590/ S0036-46652014000100004. PMid:24553605.

RALL, V., SFORCIN, J., AUGUSTINI, V., WATANABE, M., FERNANDES JUNIOR, A., RALL, R., SILVA, M.G. and ARAÚJO JUNIOR, J.P., 2010. Detection of enterotoxin genes of Staphylococcus sp isolated from nasal cavities and hands of food handlers. Brazilian Journal of Microbiology, vol. 41, no. 1, pp. 59-65. http://dx.doi. org/10.1590/S1517-83822010000100011. PMid:24031464.

SAKLANI, P., LEKSHMI, M., NAYAK, B.B. and KUMAR, S., 2020. Survival of Methicillin-Resistant Staphylococcus aureus in fish and Shrimp under different storage conditions. Journal of Food Protection, vol. 83, no. 5, pp. 844-848. http://dx.doi. org/10.4315/JFP-19-546. PMid:31928413.

SAMAD, A., ABBAS, F., AHMED, Z., AKBAR, A., NAEEM, M., SADIQ, M.B., ALI, I., SAIMA., ROOMEELA., BUGTI, F.S. and ACHAKZAI, S.K., 2019. Prevalence, antimicrobial susceptibility, and virulence of Campylobacter jejuni isolated from chicken meat. Journal of Food Safety, vol. 39, no. 2, pp. e12600. http://dx.doi. org/10.1111/jfs.12600.

SAMANTA, I. and BANDYOPADHYAY, S., 2020. Antimicrobial resistance in agriculture: perspective, policy and mitigation, Cambridge: Academic Press. Staphylococcus, pp. 195-215. http://dx.doi. org/10.1016/B978-0-12-815770-1.00016-X.

TAVAKOLI, H., SOLTANI, M. and BAHONAR, A., 2012. Isolation of some human pathogens from fresh and smoked shad. Iranian Journal of Fisheries Science, vol. 11, no. 2, pp. 424-429.

VAIYAPURI, M., JOSEPH, T.C., RAO, B.M., LALITHA, K.V. and PRASAD, M.M., 2019. Methicillin-Resistant Staphylococcus aureus in Seafood: prevalence, laboratory detection, clonal nature, and control in seafood chain. Journal of Food Science, vol. 84, no. 12, pp. 3341-3351. http://dx.doi.org/10.1111/1750-3841.14915. PMid:31769517.

YAHYA, M., ALI, H.A., GORISH, B.M.T., ALI, S.O., ABDALRHIM, E.S.A., MERGANI, M.H., ABD ELGADIR, A.A., MOHAMMED, S.K., AHMED, S.O., MUSA, N.A., AHMED, A.S., ABDALLA, W.M., HAMEDELNIL, Y. F., HASHIM, A.I., and ALTAYEB, H.N., 2020. Molecular detection of Staphylococcal enterotoxins and mecA genes products in food samples collected from different areas in Khartoum state. In Review, pp. 1-19. http://dx.doi.org/10.21203/rs.3.rs-59354/v1.

ZAHOOR, S. and BHATIA, A., 2007. Bacteria: silent killers in food. Scientific Reports, vol. 2007, pp. 33-34. 


\section{Supplementary Material}

Supplementary material accompanies this paper.

Figure S1. 2\% agarose gel electrophoresis shows amplified genes. Lane M= marker with $1000 \mathrm{bp}$. Lane C+ = positive control, Lane C- = negative control, Lanes 1,2,3,4 and 5 = positive samples for 16srRNA (228 bp)

Figure S2. Shows gel electrophoresis of amplified product of isolates. Lane M = Marker (1000bp). Lane C- = Negative control, Lane C $+=$ Positive control, Lanes 1, 2, 3 and $4=$ Positive samples for SEA (270bp) gene

This material is available as part of the online article from http://www.scielo.br/bjb 